\title{
PENGARUH KEPEMILIKAN MANAJERIAL, PROPORSI KOMISARIS INDEPENDEN TERHADAP KUALITAS LABA
}

\author{
Pedi Riswandi \\ Dosen Fakultas Ekonomi Universitas Prof. Dr. Hazairin, SH Bengkulu
}

\begin{abstract}
ABSTRAK
Pedi Riswandi; Struktur kepemilikan sangat penting karena berkaitan erat dengan pengendalian operasional perusahaan. Dari sudut pandang teori akuntansi, manajemen laba sangat ditentukan oleh motivasi manajer perusahaan.Motivasi yang berbeda akan menghasilkan besaran manajemen laba yang berbeda, seperti antara manajer yang juga pemegang saham perusahaan dengan manajer yang bukan sebagai pemegang saham dan komposisi dewan komisaris juga memegang peranan penting dalam pengawasan terhadap apa yang dilakukan oleh pihak eksekutif.Penelitian ini bertujuan untuk mengetahui pengaruh kepemilikan manajerial dan prporsi komisaris independen Sampel penelitian menggunakan perusahaan manufaktur yang terdaftar di Bursa Efek Indonesia tahun2008 - 2011. Teknik pengambilan sampel purposive sampling method. Hasil penelitian ini menunjukkan bahwa kepemilikan manajerial berpengaruh negatif terhadap kualitas laba,proporsi komisaris dependen berpengaruh positif terhadap kualitas laba
\end{abstract}

\begin{abstract}
Pedi Riswandi; Ownership structure is very important because it is closely related to the operational control of the company. From the point of view of the theory of accounting, earnings management is determined by the motivation of the company manager. Different motivations will result in a different amount of earnings management, such as the manager who also shareholders of the company with a manager who is not a shareholder and board composition also plays an important role in control of what is done by the executive This study aimed to determine the effect of managerial ownership on earnings quality and the proportion of independent directors on the quality of earnings. The research sample using companies listed in Indonesia Stock Exchange in 2009-2011. "The technique of purposive sampling method. "These results indicate that managerial ownership has a negative effect on the quality of earnings, proportion of independent directors has a positive effect on the quality of earnings.
\end{abstract}

Key words: Managerial ownership, Proportion Independent Commissioner , Earnings Quality

\section{PENDAHULUAN}

Laporan keuangan merupakan alat komunikasi yang digunakan manajemen untuk memberikan informasi yang bermanfaat bagi pihak-pihak yang berkepentingan terhadap perusahaan. Penyampaian informasi melalui laporan keuangan tersebut dilakukan untuk memenuhi kebutuhan pihak-pihak eksternal maupun internal yang kurang memiliki wewenang untuk memperoleh informasi yang mereka butuhkan dari sumber langsung perusahaan (Boediono, 2005).Para pengguna laporan keuangan (investor, kreditor, dan stakeholder lainnya) menggunakan informasi tersebut untuk mendukung pengambilan keputusan mereka.Oleh karena itu, para stakeholder mengharapkan agar perusahaan menyajikan laporan keuangan yang relevan dan jujur dalam penyajiannya, sehingga dapat menggambarkan keadaan perusahaan yang sesungguhnya.

Subramanyam (1996)menyatakan bahwa salah satu ukuran kinerja perusahaan yang sering digunakan sebagai dasar pengambilan keputusan adalah laba yang dihasilkan perusahaan. Menurut Schipper dan Vincent (2003), kualitas laba khususnya dan kualitas laporan keuangan pada umumnya adalah penting bagi mereka yang menggunakan laporan keuangan karena untuk tujuan kontrak dan pengambilan keputusan investasi. Bagi pemilik saham atau investor, laba berarti peningkatan nilai ekonomis (wealth) yang akan diterima, 
melalui pembagian dividen (Boediono, 2005). Oleh karena itu, laba merupakan salah satu informasi yang dipertimbangkan oleh para investor dan stakeholder lainnya.

Menurut Scott (2000), terdapat dua tujuan manajemen perusahaan untuk melakukan praktik manajemen laba.Pertama manajemen berusaha untuk menambah tingkat transparansi laba dalam mengkomunikasikan hal yang bersifat informasi internal perusahaan, dalam hal ini pengelolaan laba yang dilakukan bersifat efisien.Sedangkan yang kedua adalah manajemen perusahaan berusaha untuk memaksimalkan keuntungan bagi dirinya sendiri, dalam hal ini pengelolaan laba bersifat oportunistik.Manajemen laba tersebut mempunyai dampak terhadap kebermanfaatan informasi laba dalam pengambilan keputusan para pemangku kepentingan.

Untuk mengembalikan kepercayaan para investor, maka perusahaan diharapkan memiliki tata kelola perusahaan (corporate governance) yang sehat. Hasil analisis yang dilakukan berbagai organisasi internasional dan regulator pemerintah dibanyak negara menemukan penyebab utama terjadinya krisis ekonomi adalah karena lemahnya corporate governance di banyak perusahaan.

Menurut teori keagenan, untuk mengatasi masalah ketidakselarasan kepentingan antara principal dan agent dapat dilakukan melalui pengelolaan perusahaan yang baik (Midiastuty dan Machfoedz, 2003). Sebagaimana diungkapkan oleh Veronica dan Bachtiar (2004) corporate governance adalah salah satu cara untuk mengendalikan tindakan oportunistik yang dilakukan manajemen. Ada empat mekanisme corporate governance yang dapat digunakan untuk mengatasi konflik keagenan, yaitu meningkatkan kepemilikan manajerial, meningkatkan kepemilikan institusional, komisaris independen dan komite audit (Rachmawati dan Triatmoko, 2007).Sutojodan Aldridge (2005) menjelaskan bahwa dengan menerapkan sistem tata kelola perusahaan yang baik maka perusahaan akan mengungkapkan informasi perusahaan secara transparan dan akan lebih melindungi hak dan kepentingan pemegang saham serta dapat meningkatkan nilai perusahaan.

Struktur kepemilikan sangat penting karena berkaitan erat dengan pengendalian operasional perusahaan. Dari sudut pandang teori akuntansi, manajemen laba sangat ditentukan oleh motivasi manajer perusahaan.Motivasi yang berbeda akan menghasilkan besaran manajemen laba yang berbeda, seperti antara manajer yang juga pemegang saham perusahaan dengan manajer yang bukan sebagai pemegang saham (Boediono, 2005). Dengan meningkatkan kepemilikan saham oleh manajer, diharapkan manajer akan bertindak sesuai dengan keinginan prinsipal karena manajer akan termotivasi untuk meningkatkan kerja.Hal ini didukung oleh hasil penelitian yang dilakukan oleh Dhaliwal, et al. (1982),Morck, et al. (1988),Warfield, et al. (1995),Gabrielsen, et al. (2002)dan Midiastuty dan Mahfoedz (2003), yang memberikan kesimpulan bahwa perusahaan yang dikelola oleh manajer dan memiliki presentase tertentu pada saham perusahaan dapat mempengaruhi tindakan manajemen laba.

Selain kepemilikan manajerial, komposisi dewan komisaris juga memegang peranan penting dalam pengawasan terhadap apa yang dilakukan oleh pihak eksekutif atau direksi. Fungsi utama Dewan komisaris menurut Indonesian Code For Corporate Governance adalah memberikan supervisi kepada direksi dalam menjalankan tugasnya dan berkewajiban memberikan pendapat serta saran apabila diminta direksi. Dalam menjalankan tugasnya anggota dewan komisaris harus bersikap independen. Oleh karena itu, dalam keanggotaan dewan komisaris harus terdapat anggota dari luar perusahaan yang independen.

Manajemen laba yang dilakukan oleh pihak manajer, dapat mempengaruhi kualitas informasi yang dihasilkan, terutama informasi laba. Manajer akan cenderung mementingkan dirinya sendiri dan mengabaikan kepentingan pihak lain, sehingga manajer cenderung untuk memanipulasi kinerja perusahaan yang dilaporkan. Penelitian Subramanyam (1996), Pae (1999), Sankar (1999) dan Teixeira (2002), menyimpulkan adanya manajemen laba pada perusahaan dapat mempengaruhi kualitas laba yang dilaporkan.

Penelitian ini didasarkan pada penelitian yang dilakukan oleh Jaggi, et al. (2009) dengan sampel perusahaan Hongkong. Hasil penelitian ini mendoku-mentasikan bahwa pemantauan yang dilakukan oleh dewan komisaris independen pada perusahaan-perusahaan di Hongkong, yang memiliki kepemilikan terkonsen-trasi, menyediakan pemantauan yang efektif terhadap manajemen laba.Penelitian juga menemukan bahwa hubungan antara independensi dewan 
komisaris dengan manajemen laba diperlemah dengan konsentrasi kepemilikan atau kehadiran anggota keluarga pada keanggotaan dewan komisaris. Dengan latar belakang yang sudah dipaparkan diatas, maka penelitian ini ingin lebih memfokuskan pada kepemilikan manajerial serta peran pengawasan dari dewan komisaris yang independen terhadap kualitas laba, dengan mengambil judul "Pengaruh Kepemilikan Manajerial, Proporsi Komisaris Independen terhadap Kualitas Laba".

\section{Landasan Teori}

\section{Teori Keagenan (Agency Theory)}

Perspektif agency theory merupakan dasar yang digunakan untuk memahami corporate governance. Menurut Jensen dan Meckling (1976) agency theory adalah sebuah kontrak antara manajer (agent) dengan pemilik (principal). Agar hubungan kontraktual ini dapat berjalan dengan lancar, pemilik akan mendelegasikan otoritas pembuatan keputusan kepada manajer. Perencanaan kontrak yang tepat untuk menyelaraskan kepentingan manajer dan pemilik dalam hal konflik kepentingan inilah yang merupakan inti dari agency theory. Namun untuk menciptakan kontrak yang tepat merupakan hal yang sulit diwujudkan. Oleh karena itu, investor diwajibkan untuk memberi hak pengendalian residual kepada manajer (residual control right) yakni hak untuk membuat keputusan dalam kondisi-kondisi tertentu yang sebelumnya belum terlihat di kontrak.

Teori keagenan dilandasi oleh beberapa asumsi (Eisenhardt, 1989). Asumsi-asumsi tersebut dibedakan menjadi tiga jenis, yaitu asumsi tentang sifat manusia, asumsi keorganisasian dan asumsi informasi. Asumsi sifat manusia menekankan bahwa manusia memiliki sifat mementingkan diri sendiri (self-interest), manusia memiliki daya pikir terbatas mengenai persepsi masa mendatang (bounded rationality), dan manusia selalu menghindari resiko (risk averse). Asumsi keorganisasian adalah adanya konflik antar anggota organisasi, efisiensi sebagai kriteria efektivitas dan adanya asimetri informasi antara principal dan agent. Asumsiinformasi adalah bahwa informasi sebagai barang komoditi yang dapat diperjualbelikan.

Teori keagenan berusaha untuk menjawab masalah keagenan yang terjadi jika pihakpihak yang saling bekerja sama memiliki tujuan dan pembagian kerja yang berbeda. Secara khusus teori keagenan membahas tentang adanya hubungan keagenan, dimana suatu pihak tertentu (principal) mendelegasikan pekerjaan kepada pihak lain (agent) yang melakukan perkerjaan. Teori keagenan ditekankan untuk mengatasi dua permasalahan yang dapat terjadi dalam hubungan keagenan (Eisenhardt, 1989). Pertama adalah masalah keagenan yang timbul pada saat (a) keinginan-keinginan atau tujuan-tujuan dari prinsipal dan agen berlawanan dan (b) merupakan suatu hal yang sulit atau mahal bagi prinsipal untuk melakukan verifikasi tentang apa yang benar-benar dilakukan oleh agen. Permasalahannya adalah bahwa prinsipal tidak dapat memverifikasi apakah agen telah melakukan sesuatu secara tepat. Kedua adalah masalah pembagian resiko yang timbul pada saat prinsipal dan agen memiliki sikap yang berbeda terhadap resiko. Dengan demikian, prinsipal dan agen mungkin memiliki preferensi tindakan yang berbeda dikarenakan adanya perbedaan preferensi resiko.

\section{Corporate Governance}

Corporate Governance mempunyai lima macam tujuan utama. Kelima tujuan tersebut antara lain melindungi hak dan kepentingan pemegang saham, melindungi hak dan kepentingan para anggota stakeholder non pemegang saham, meningkatkan nilai perusahaan dan para pemegang saham, meningkatkan efisiensi dan efektifitas kerja dewan pengurus dan manajemen perusahaan serta meningkatkan mutu hubungan dewan pengurus dengan manajemen senior perusahaan.Setiap perusahaan harus memastikan bahwa asas Good Corporate Governance (GCG) diterapkan pada setiap aspek bisnis dan di semua jajaran perusahaan. Ada lima Asas GCG yaitu (KNKG, 2006) : 


\section{Transparansi (Transparency)}

Untuk menjaga obyektivitas dalam menjalankan bisnis, perusahaan harus menyediakaninformasi yang material dan relevan dengan cara yang mudah diakses dan dipahamioleh pemangku kepentingan. Perusahaan harus mengambil inisiatif untuk mengungkapkantidak hanya masalah yang disyaratkan oleh peraturan perundang-undangan, tetapijuga hal yang penting untuk pengambilan keputusan oleh pemegang saham, krediturdan pemangku kepentingan lainnya.

\section{Akuntabilitas (Accountability)}

Perusahaan harus dapat mempertanggungjawabkan kinerjanya secara transparan danwajar. Untuk itu perusahaan harus dikelola secara benar, terukur dan sesuai dengankepentingan perusahaan dengan tetap memperhitungkan kepentingan pemegang sahamdan pemangku kepentingan lain. Akuntabilitas merupakan prasyarat yang diperlukanuntuk mencapai kinerja yang berkesinambungan.

\section{Responsibilitas (Responsibility)}

Perusahaan harus mematuhi peraturan perundang-undangan serta melaksanakantanggung jawab terhadap masyarakat dan lingkungan sehingga dapat terpeliharakesinambungan usaha dalam jangka panjang dan mendapat pengakuan sebagaigood corporate citizen.

\section{Independensi (Independency)}

Untuk melancarkan pelaksanaan asas GCG, perusahaan harus dikelola secaraindependen sehingga masing-masing organ perusahaan tidak saling mendominasi dantidak dapat diintervensi oleh pihak lain.

\section{Kewajaran dan Kesetaraan (Fairness)}

Dalam melaksanakan kegiatannya, perusahaan harus senantiasa 'memperhatikankepentingan pemegang saham dan pemangku kepentingan lainnya berdasarkanasas kewajaran dan kesetaraan.

\section{Eksekutif (Direksi) Perusahaan dan Komposisi Dewan.}

\section{Rapat Umum Pemegang Saham}

RUPS sebagai organ perusahaan merupakan wadah para pemegang saham untukmengambil keputusan penting yang berkaitan dengan modal yang ditanam dalamperusahaan, dengan memperhatikan ketentuan anggaran dasar dan peraturanperundang-undangan.Keputusan yang diambil dalam RUPS harus didasarkan padakepentingan usaha perusahaan dalam jangka panjang. RUPS dan atau pemegang saham tidak dapat melakukan intervensi terhadap tugas, fungsi dan wewenang Dewan Komisaris dan Direksi dengan tidak mengurangi wewenang RUPS untuk menjalankan haknya sesuai dengan anggaran dasar dan peraturan perundangundangan,termasuk untuk melakukan penggantian atau pemberhentian anggota Dewan Komisaris dan atau Direksi.

\section{Dewan Komisaris dan Direksi}

Kepengurusan perseroan terbatas di Indonesia menganut sistem dua badan (twoboardsystem) yaitu Dewan Komisaris dan Direksi yang mempunyai wewenang dantanggung jawab yang jelas sesuai dengan fungsinya masing-masing sebagaimanadiamanahkan dalam anggaran dasar dan peraturan perundang-undangan (fiduciary responsibility).Namun demikian, keduanya mempunyai tanggung jawab untukmemelihara kesinambungan usaha perusahaan dalam jangka panjang.Oleh karenaitu, Dewan Komisaris dan Direksi harus memiliki kesamaan persepsi terhadap visi, misi, dan nilai-nilai perusahaan.misi dan nilai-nilai perusahaan.

\section{a. Dewan Komisaris}

Dewan Komisaris sebagai organ perusahaan bertugas dan bertanggungjawab secarakolektif untuk melakukan pengawasan dan memberikan nasihat kepada Direksi sertamemastikan bahwa perusahaan melaksanakan GCG.Namun demikian, Dewan Komisaris tidak boleh turut serta dalam mengambil keputusan operasional.Kedudukan masing-masing anggota Dewan Komisaris termasuk Komisaris Utama adalah 
setara.Tugas Komisaris Utama sebagai primus inter pares adalah mengkoordinasikan kegiatan Dewan Komisaris. Agar pelaksanaan tugas Dewan Komisaris dapat berjalan secara efektif, perlu dipenuhi prinsip-prinsip berikut:

1) Komposisi Dewan Komisaris harus memungkinkan pengambilan keputusan secaraefektif, tepat dan cepat, serta dapat bertindak independen.

2) Anggota Dewan Komisaris harus profesional, yaitu berintegritas dan memilikikemampuan sehingga dapat menjalankan fungsinya dengan baik termasukmemastikan bahwa Direksi telah memperhatikan kepentingan semua pemangkukepentingan.

3) Fungsi pengawasan dan pemberian nasihat Dewan Komisaris mencakup tindakanpencegahan, perbaikan, sampai kepada pemberhentian sementara.

Dalam melaksanakan tugasnya, Dewan Komisaris dapat membentuk komite.Usulan dari komite disampaikan kepada Dewan Komisaris untuk memperolehkeputusan. Bagi perusahaan yang sahamnya tercatat di bursa efek, perusahaannegara, perusahaan daerah, perusahaan yang menghimpun dan mengelola dana masyarakat, perusahaan yang produk atau jasanya digunakan olehmasyarakat luas, serta perusahaan yang mempunyai dampak luas terhadapkelestarian lingkungan, sekurang-kurangnya harus membentuk Komite Audit, sedangkan komite lain dibentuk sesuai dengan kebutuhan.

b. Direksi

Direksi sebagai organ perusahaan bertugas dan bertanggungjawab secara kolegialdalam mengelola perusahaan.Masing-masing anggota Direksi dapat melaksanakan tugas dan mengambil keputusan sesuai dengan pembagian tugas dan wewenangnya.Namun, pelaksanaan tugas oleh masing-masing anggota Direksi tetap merupakan tanggung jawab bersama.Kedudukan masing-masing anggota Direksi termasuk Direktur Utama adalah setara.Tugas Direktur Utama sebagai primus inter pares adalah mengkoordinasikan kegiatan Direksi. Agar pelaksanaan tugas Direksi dapat berjalan secara efektif, perlu dipenuhi prinsip-prinsip berikut:

1) Komposisi Direksi harus sedemikian rupa sehingga memungkinkan pengambilankeputusan secara efektif, tepat dan cepat, serta dapat bertindak independen.

2) Direksi harus profesional yaitu berintegritas dan memiliki pengalaman sertakecakapan yang diperlukan untuk menjalankan tugasnya.

3) Direksi bertanggung jawab terhadap pengelolaan perusahaan agar dapatmenghasilkan keuntungan (profitability) dan memastikan kesinambungan usahaperusahaan.

4) Direksi mempertanggungjawabkan kepengurusannya dalam RUPS sesuai denganperaturan perundang-undangan yang berlaku.

\section{Kualitas Laba}

Tujuan utama pelaporan laba adalah memberikan informasi yang berguna bagi pihakpihak yang berkepentingan dalam laporan keuangan. Tujuan yang lebih spesifik adalah penggunaan laba sebagai pengukuran efisiensi manajemen, penggunaan angka laba historis untuk membantu meramalkan arah masa depan dari perusahaan atau pembagian dividen masa depan, penggunaan laba sebagai pengukuran pencapaian dan sebagai pedoman untuk keputusan manajerial masa depan (Hendriksen, 2000). Laba yang digunakan sebagai pengukuran efisiensi manajemen dapat menjadi pendorong manajemen untuk melakukan manipulasi terhadap laba. Konflik keagenan yang diakibatkan dari sifat oportunistis dari manajemen akan mengakibatkan rendahnya kualitas laba. Rendahnya kualitas laba, akan dapat membuat keputusan yang diambil oleh para investor dan pihak-pihak lain yang berkepentingan kurang akurat, karena informasi tersebut tidak sesuai dengan kondisi yang sesungguhnya.

Penelitian yang dilakukan oleh Sloan (1996), menguji sifat kandungan informasi komponen akrual dan komponen aliran kas, apakah informasi tersebut terefleksi dalam harga saham. Ditemukan bukti bahwa kinerja laba yang teratribut pada komponen akrual 
menggambarkan tingkat persistensi yang rendah jika dibandingkan pada kinerja laba yang teratribut dalam komponen aliran kas.

Berdasarkan penelitian dari Wu (2005), ada beberapa faktor yang mempengaruhi kulitas laba yaitu antara lain standar akuntansi, karakteristik perusahaan, karakteristik dewan dan audit komite, karakteristik manajerial, karakteristik kantor audit dan faktor-faktor lain. Terdapat tiga kategori yang luas untuk memproksikan kualitas laba, yaitu diantaranya sifat laba itu sendiri, tanggapan investor terhadap labadan indikator eksternal dari kualitas laporan keuangan (Dechow, 2009). Sifat dari laba meliputi persistensi dan akrual, earning smoothness, ketepatan waktu asimetris dan pengakuan kerugian yang tepat waktu serta pembandingan (benchmarking), dimana jarak laba dari benchmark dipandang sebagai ukuran kualitas. Sedangkan ketanggapan investor (investor responsiveness) menggunakan koefisien respon laba (ERC) sebagai ukuran keinformatifan laba atau kulitas respon laba. Untuk kategori indikator eksternal dari kualitas pelaporan keuangan meliputi AAERs, restatement, dan prosedur pengendalian internal yang dilaporkan dalam SOX.

\section{Hipotesis}

H1 : Kepemilikan saham manajerial berpengaruh positif terhadap kualitas laba H2: Proporsi komisaris independen berpengaruh positif terhadap kualitas lab

\section{HASIL DAN PEMBAHASAN Statistik Deskriptif}

Tabel 1. Statistik Deskriptif Variabel Penelitian

\begin{tabular}{|l|c|c|c|c|}
\hline Variabel & \multicolumn{1}{c}{ Minimum } & \multicolumn{1}{c|}{ Maksimum } & Mean & Std. Deviation \\
\hline KL & -0.47 & 0.56 & -0.0035 & 0.15383 \\
\hline KSM & 0 & 7.69 & 1.0573 & 2.04935 \\
\hline KPIn & 0.20 & 0.80 & 0.3924 & 0.10131 \\
\hline
\end{tabular}

\section{Sumber : Data Sekunder Diolah, 2013}

Berdasarkan statistik deskriptif yang tersaji pada tabel 1. menunjukkan kualitas laba yang diukur dengan manajemen laba(KL) dengan menggunakan discretionary accruals dengan menggunakan Jones Modified memiliki nilairata-ratasebesar -0.0035 . Nilai rata-rata dari Manajemen Laba dari sampel penelitian menunjukkan adanya kemungkinan bahwa rata-rata sampel dalam penelitian ini melakukan manajemen laba dengan cara menurunkan laba (income decreasing) dengan nilai standar deviasi sebesar 0.15383. Nilai standar deviasi dari kualitas laba yang diukur dengan manajemen laba yang lebih besar dari nilai rata-rata menunjukkan bahwa adanya variasi manajemen laba yang dilakukan oleh perusahaan yang dijadikan sampel dalam penelitian ini (lebih dari 15 persen dari mean). Manajemen laba dengan nilai minimum sebesar- 0.47 berarti bahwa manajemen laba yang dilakukan oleh perusahaan yang dijadikan sampel penelitian berupa manajemen laba dalam bentuk penurunan laba dan manajemen laba yang bernilai maksimum sebesar 0,56 berarti bahwa manajemen laba yang dilakukan perusahaan yang dijadikan sampel dalam penelitian melakukan manajemen laba dalam bentuk meningkatkan laba.

Kepemilikan Manajerial (KSM) memiliki nilai rata-rata sebesar 1.0573 yang berarti bahwa rata-rata kepemilikan manajerial yang dijadikan sampel dalam penelitian adalah 1,0573\%. Standar deviasi dari variabel KSM adalah sebesar 2.04935 dimana dengan membandingkan nilai standar deviasi dengan nilai rata-ratanya menunjukkan bahwa ada variasi yang cukup tinggi dari variabel kepemilikan manajerial. Hasil deskriptif statistik selanjutnya untuk variabel kepemilikan manajerial menunjukkan nilai minimum sebesar $0 \%$ yang berarti bahwa perusahaan yang dijadikan sampel dalam penelitian ini tidak memiliki kepemilikan manajerial dan nilai maksimum sebesar 7,69\% berarti bahwa jumlah kepemilikan manajerial dari perusahaan yang dijadikan sampel dalam penelitian ini hanya sebesar 7,69\%. Hasil deskriptif statistik menunjukkan bahwa jumlah saham yang dimiliki oleh manajerial 
dalam penelitian ini relatif sedikit untuk perusahaan-perusahaan yang dijadikan sampel dalam penelitian ini.

Variabel proporsi komisaris independen terhadap total komisaris (KPIn) memiliki nilai rata-rata sebesar 0.3924 atau sebesar $39.24 \%$ dari seluruh jumlah komisaris yang dimiliki oleh suatu perusahaan yang dijadikan sampel penelitian adalah komisaris independen dan sisanya sebesar $60.76 \%$ dipegang oleh komisaris non independen. Nilai standar deviasi dari variabel KPIn adalah0.10131 yang menunjukkan bahwa variasi komisaris independen terhadap total komisaris dari seluruh sampel penelitian adalah $10.131 \%$. Dengan membandingkan antara nilai standar deviasi dan nilai rata-rata dari variabel KPInmenunjukkan bahwa variabel KPIn (proporsi komisaris independen terhadap total komisaris) menunjukkan bahwa variabel KPIn tidak memiliki variasi yang cukup tinggi.

\section{Uji Normalitas}

Uji Asumsi Klasik yang pertama adalah uji normalitas.Uji normalitas data bertujuan untuk menguji apakah dalam model regresi, variabel pengganggu atau residual memiliki distribusi normal (Ghozali, 2005). Uji normalitas yang digunakan dalam penelitian ini adalah uji Kolmogorov-Smirnov dengan menggunakan taraf signifikan 0,05, jika data tersebut mempunyai level of significance sama atau di atas $5 \%(\alpha \geq 0.05)$ maka data tersebut terdistribusi secara normal, sedangkan jika data kurang dari $5 \%(\alpha \leq 0.05)$ maka data tersebut tidak terdistribusi secara normal. Hasil pengujian seluruh data mentah dapat dilihat pada Tabel 2. dibawah ini:

Tabel 2. Hasil Uji Normalitas Sebelum Diobati

\begin{tabular}{|l|c|c|l|}
\hline Variabel & Kolmogorov-Smirnov & Asymp.Sig & \multicolumn{1}{c|}{ Keterangan } \\
\hline KL & 1.337 & 0.056 & Data Normal \\
\hline SKM & 3.857 & 0.000 & Data Tidak Normal \\
\hline PKIn & 2.832 & 0.000 & Data Tidak Normal \\
\hline
\end{tabular}

Sumber : Data Sekunder Diolah, 2013

\section{Uji Multikolinearitas}

Uji Multikolinearitas bertujuan untuk mengetahui apakah tiap-tiap variabel independen saling berhubungan secara linear.Uji Multikolinearitas juga digunakan untuk mengetahui apakah antar variabel bebas yang terdapat dalam model memiliki hubungan yang sempurna atau mendekati sempurna. Dalam penelitian ini, untuk mendeteksi ada tidaknya multikolinearitas dapat dilihat dari nilai tolerance dan variance inflation factor (VIF). Tolerance mengukur variability variabel bebas yang terpilih yang tidak dapat dijelaskan oleh variabel bebas lainnya, jadi nilai tolerance yang rendah sama dengan VIF tinggi (VIF $=1$ /tolerance) dan menunjukkan adanya kolinearitas yang tinggi. Nilai yang dipakai untuk menandai adanya faktor multikolinearitas adalah nilai tolerance $>0.10$ atau sama dengan nilai VIF $<10$. Berdasarkan hasil regresi variabel independen dan variabel dependen, menghasilkan nilai tolerance dan VIF pada tiap-tiap persamaan pada Tabel 3. di bawah ini:

\section{Tabel 3. Uji Multikolinearitas}

\begin{tabular}{|c|c|c|c|}
\hline Persamaan dan & \multicolumn{2}{|c|}{ Kriteria } & Keputusan \\
\hline Variabel & Tolerrance & VIF & \\
\hline SKM & 0.872 & 1.147 & Bebas Multikolinearitas \\
\hline PKIN & 0.774 & 1.292 & Bebas Multikolinearitas \\
\hline
\end{tabular}

\section{Sumber : Data Sekunder Diolah, 2013}

Berdasarkan Tabel 3. di atas hasil pengujian menunjukkan nilai tolerance $<0,1$ dan nilai VIF $>10$, sehingga dapat diambil kesimpulan bahwa variabel dalam penelitian ini bebas dari masalah multikolinearitas. 


\section{Uji Autokorelasi}

Uji autokorelasi bertujuan untuk menguji apakah dalam suatu model regresi linear untuk pengujian hipotesis terdapat korelasi antara kesalahan pengganggu pada periode $\mathrm{t}$ dengan kesalahan pengganggu pada periode t-1 (sebelumnya), jika terjadi korelasi maka terdapat masalah autokorelasi karena adanya korelasi pada tempat yang berdekatan dan menimbulkan konsekuensi, yaitu interval keyakinan menjadi lebar, serta varians dan kesalahan standar akan ditaksir terlalu rendah. Model regresi yang baik adalah tidak terdapat autokorelasi.Pendekatan yang digunakan untuk menguji ada atau tidaknya autokorelasi adalah dengan menggunakan uji Durbin-Watson.

\section{Tabel 4. Uji Autokorelasi}

\begin{tabular}{|c|c|c|c|c|c|c|c|c|}
\hline H & Persamaan & $\mathbf{N}$ & $\mathbf{K}$ & DI & Du & DW & Kriteria & Keterangan \\
\hline 1 & SKM & 92 & 1 & 1.5249 & 1.8016 & 2.409 & $4-\mathrm{dl}<\mathrm{d}<4$ & $\begin{array}{c}\text { Tidak Ada } \\
\text { Autokolerasi } \\
\text { negatif }\end{array}$ \\
\hline 2 & PKIn & 93 & 6 & 1.5282 & 1.8018 & 2.287 & $4-\mathrm{dl}<\mathrm{d}<4$ & $\begin{array}{c}\text { Tidak Ada } \\
\text { Autokolerasi } \\
\text { negatif }\end{array}$ \\
\hline
\end{tabular}

\section{Sumber : Data Sekunder Diolah, 2013}

\section{Uji Heteroskedastisitas}

\section{Tabel 5. Uji Heteroskedastisitas}

\begin{tabular}{|l|c|c|c|}
\hline & T & \multicolumn{2}{c|}{ Keputusan } \\
\cline { 1 - 2 } Konstanta & (Sig.) & (Sig.) & \\
& 0.156 & 0.917 & \\
\hline SKM & $(0.255)$ & $(0.474)$ & Bebas Heteroskedastisitas \\
& -0.572 & 0.357 & \\
\hline PKIN & $(0.569)$ & $(0.784)$ & Bebas Heteroskedastisitas \\
& -0.018 & & \\
\hline
\end{tabular}

\section{Sumber : Data Sekunder Diolah, 2013}

Hasil pengujian heteroskedastisitas menunjukkan bahwa dengan melihat nilai signifikansi t (secara parsial) dan signifikansi nilai $\mathrm{F}$ (secara bersama-sama), hasil pengujian heteroskedastisitas menyimpulkan bahwa seluruh variabel yang digunakan dalam penelitian ini baik secara parsial maupun secara keseluruhan bebas dari masalah heteroskedastisitas.

\section{Uji F}

Uji F digunakan untuk mengetahui apakah model yang digunakan dalam regresi telah sesuai (goodness of fit model).

\section{Tabel 6. Hasil Uji Kelayakan Model}

\begin{tabular}{|c|c|c|c|}
\hline Model & F-Hitung & Signifikan & $\begin{array}{c}\text { F-tabel } \\
(n=125)\end{array}$ \\
\hline KSM & 3.012 & 0.034 & 2,60 \\
\hline KPIN & 1.942 & 0.020 & \\
\hline
\end{tabular}

\section{Sumber : Data Sekunder Diolah, 2013}

Berdasarkan Tabel 6. uji F diatas dapat dilihat bahwa pada hipotesis pertama masingmasing menunjukkan menunjukkan nilai F-hitung yang dihasilkan dari hasil regresi sebesar 3.012 dan dengan tingkat signifikansi $\sigma<5 \%$ (Signifikan pada tingkat 47,4\% di bawah 5\%). Dari nilai signifikansi $\sigma<5 \%$ dan nilai F-hitung lebih besar dari F-tabel dapat disimpulkan bahwa model regresi adalah model yang baik.

Hasil pengujian kelayakan model selanjutnya untuk hipotesis kedua hasil regresimenghasilkan nilai F-hitung sebesar 1.942 dan signifikan pada $\sigma<5 \%$ (signifikansi 
sebesar 1\% dibawah 5\%). Dengan melihat tingkat signifikansi F di bawah 5\% dan nilai F-hitung $>$ F-tabel disimpulkan bahwa model regresi kedua juga dianggap sebagai model yang baik.

\section{Pengujian Hipotesis dan Pembahasan}

Hipotesis pertama dalam penelitian ini bertujuan untuk melihat pengaruh kepemilikan saham manajerial dan proporsi dewan komisaris terhadap kualitas laba. Hasil regresi untuk hipotesis 1 dan 2 dapat dilihat pada tabel 7. dibawah ini :

Tabel 7. Hasil Uji Hipotesis 1

\begin{tabular}{|c|c|c|}
\hline \multirow[b]{2}{*}{ Variabel } & \multicolumn{2}{|c|}{ VariabelIndependen } \\
\hline & Koefisien & $\begin{array}{c}\mathrm{t} \\
\text { (Sig.) }\end{array}$ \\
\hline \multicolumn{3}{|l|}{ Konstanta } \\
\hline SKM & -0.005 & $\begin{array}{c}-2.004 \\
(0.049)\end{array}$ \\
\hline $\mathrm{R}^{2}$ & 0.057 & \\
\hline Adj R ${ }^{2}$ & 0.042 & \\
\hline $\mathrm{F}$ & 4.018 & \\
\hline Sig. & 0.049 & \\
\hline
\end{tabular}

Sumber : Data Sekunder Diolah, 2013

Untuk pengujian hipotesis pertama yang ditujukan untuk menguji apakah kepemilikan saham manajerial berpengaruh negatif terhadap kualitas laba yang diukur dengan manajemen laba pengaruh dari kepemilikan manajerial tersebut terhadap kualitas laba adalah tidak signifikan koefisien regresi yang dihasilkan adalah negatif sebesar 0.002 dan tidak signifikan $(\sigma$ $>5 \%$ ). Koefisien regresi yang negatif dan tidak signifikan Koefisien regresi yang negatif dan tidak signifikan berarti bahwa semakin besar kepemilikan maka semakin kualitas laba yang diukur dengan manajemen laba akan semakin rendah tetapi pengaruh dari kepemilikan manajerial tersebut terhadap kualitas laba adalah tidak signifikan. Sehingga hipotesis pertama dalam penelitian ini ditolak.

Koefisien regresi yang negatif disimpulkan bahwa semakin besar kepemilikan manjerial maka semakin rendah kualitas laba yang diproksikan dengan manajemen laba atau dengan kata lain kualitas laba yang semakin rendah disebabkan manajemen laba yang semakin tinggi, Hasil penelitian ini tidak konsisten dengan beberapa hasil penelitian yang menemukan bukti bahwa dengan bertambahnya kepemilikan manajerial maka akan semakin meningkatkan kualitas laba yang berarti juga akan berdampak pada penurunan manajemen laba.

Seperti yang dinyatakan oleh Jensen dan Meckling (1976), bahwa ketika kepemilikan manajemen meningkat, kepentingan manajer terhadap perusahaan akan lebih dekat dengan kepentingan pemilik, dan kebutuhan atas monitoring dewan akan semakin rendah. Selanjutnya penelitian yang dilakukan Wu (2006), yang meneliti tentang kepemilikan manajerial terhadap kualitas laba yang diukur dengan konservatisme dalam laporan keuangan, menemukan bahwa perusahaan yang memiliki persentase kepemilikan manajerial yang lebih tinggi menunjukkan pola yang lebih konservatisme dalam melaporkan laporan keuangan. Hal ini membuktikan adanya hubungan yang positif antara kepemilikan manajerial dengan konservatisme, yang merupakan salah satu penilaian dari kualitas laba. Sehingga semakin tinggi konservatisme maka kualitas laba yang hasilkan akan semakin rendah. Perusahaan yang dikelola oleh manajer dan memiliki persentase tertentu saham perusahaan dapat mempengaruhi tindakan manajemen laba.

Dari hasil penelitian yang telah dilakukan $\mathrm{Wu}$ (2006) yang membuktikan bahwa semakin besar kepemilikan manajerial, maka akan semakin tinggi pula konservatisme yang menyebabkan kualitas laba akan semakin rendah. Dari koefisien regresi yang negatif meskipun tidak signifikan, hasil penelitian ini membuktikan bahwa kepemilikan manajerial belum cukup mampu untuk meningkatkan kualitas laba yang dilaporkan dalam laporan keuangan dengan 
cara menurunkan manajemen laba, Hal ini dimungkinkan untuk perusahaan-perusahaan yang listing di Bursa efek Indonesia, struktur kepemilikan manajerial cenderung sedikit dan lebih didominasi oleh kepemilikan keluarga. Hal ini dapat dilihat dari hasil penelitian yang telah dilakukan oleh La Porta et al., (1999 dan 2002) yang menemukan bukti bahwa kepemilikan saham publik di Indonesia cenderung dalam bentuk piramida terbalik dan kepemilikan sahamnya lebih didominasi kepemilikan keluarga (family ownership).

Hipotesis kedua dalam penelitian ini bertujuan untuk melihat pengaruh komisaris independen terhadap kualitas laba. Regresi untuk hipotesis 2 Untuk pengujian hipotesis kedua yang ditujukan untuk menguji apakah proporsi komisaris independen berpengaruh positif terhadap kualitas laba yang diukur dengan manajemen laba sebelum memasukkan variabel kontrol menunjukkan hasil koefisien regresi yang positif sebesar 2.026 dan dengan tingkat signifikansi $\alpha=0.046$ Hal ini berarti bahwa komisaris independen berpengaruh positif dan signifikan terhadap kualitas laba atau secara tidak langsung semakin banyak komisari independen dalam suatu perusahaan maka semakin baik kualitas laba yang akan dihasilkan, sehingga hipotesis kedua dalam penelitian ini diterima. Dengan diterimanya hipotesis kedua, dalam penelitian ini diduga bahwa komisaris independen mampu memainkan perannya khususnya dalam mekanisme corporate governance yang diharapkan mampu untuk mengurangi perilaku manajemen laba yang dilakukan manajemen perusahaan.

Dampak independensi dewan perusahaan terhadap efektifitas pengawasan telah diteliti oleh beberapa penelitian sebelumnya.Penelitian Fama dan Jensen (1983) menekankan pentingnya independensi dewan perusahaan untuk menyediakan monitoring yang efektif terhadap kegiatan manajerial dan inisiatif. Williamson (1981), berpendapat bahwa independensi dewan perusahaan diperlukan untuk melindungi kepentingan investor.Roe (1991), mendukung peran pemantauan perusahaan dewan di lapangan bahwa kegiatan manajerial tidak dapat ditargetkan oleh tindakan legislatif, dan berpendapat bahwa pemantauan yang efektif oleh dewan perusahaan mencegah penyalahgunaan kekuasaan oleh para manajer.

Hasil penelitian yang dilakukan oleh Klein (2002), Peasnell et al. (2001), Chtourou et al. (2001), Midiastuty dan Mahfoedz (2003), menemukan bahwa perusahaan yang memiliki anggota dewan komisaris yang berasal dari luar perusahaan atau outside directors dapat mempengaruhi tindakan manajemen laba. Hal ini juga didukung oleh penelitian yang dilakukan oleh Vafeas (2002) dan Anderson et al. (2003) yang memberikan kesimpulan bahwa komposisi dewan komisaris diperusahaan dapat mempengaruhi kualitas laba yang dilaporkan.Selanjutnya Jaggi et al. (2009) melakukan pengujian pengaruh komisaris independen terhadap kualitas laba yang diukur dengan manajemen laba pada perusahaan yang terdaftar di Hongkong dengan periode pengamatan 1998-2000. Hasil penelitian menemukan bukti bahwa moderasi antara komisaris independen dan kepemilikan keluarga menjadi suatu mekanisme yang efektif dalam membatasi manajemen laba.

\section{Kesimpulan}

Dengan mengajukan dua hipotesis yang dinyatakan dalam penelitian ini dan dengan menggunakan regresi linier berganda, kesimpulan penelitian ini adalah:

1. Kepemilikan manajerial belum mampu meningkatkan kualitas laba.

2. Proporsi komisaris independen sudah mampu meningkatkan kualitas laba.

\section{Saran}

1. Penelitian diharapkan dapat berguna bagi banyak pihak khususnya bagi para pihak yang berkepentingan dengan perusahaan yang memanfaatkan informasi keuangan dalam pengambilan keputusan. Penelitian ini diharapkan dapat digunakan bagi para pemakai laporan keuangan khususnya informasi laba dan hubungannya dengan permasalahan keagenan khususnya struktur kepemilikan dan mekanisme corporate governance yang diterapkan pada suatu perusahaan yang nantinya akan mempengaruhi kualitas laba. 
2. Penelitian ini diharapkan dapat digunakan sebagai salah satu referesni bagi peneliti selanjutnya termasuk dengan menambah variabel lainnya seperti komite audit dan pengaruh dari interaksi dari komite audit dan kepemilikan saham pengendali terhadap kualitas laba

\section{DAFTAR PUSTAKA}

Abdullah, S.N. and Mohd Nasir, N. 2004."Accrual management and the independence of the board of directors and audit committees", IIUM Journal of Economics and Management, Vol. 12 No.1, pp. 49-80.

Abdul-Rahman, R. and Mohamed Ali, F.H. 2006. "Board, audit committee, culture and earnings management: Malaysian evidence", Managerial Auditing Journal, Vol. 21 No. 7, pp. 783-804.

Achmad ,Tarmidzi., 2008. "Concentrated Family Ownership Structures Weakening Corporate Governance : A Developing Country Story The Case of Indonesian Companies."Jurnal Maksi, Vol.8, No 2, Hal. 118-134.

Aji, Dhamar Y., dan Mita, Aria F., 2010. "Pengaruh Profitabilitas, resiko Keuangan, Nilai Perusahaan, dan Struktur Kepemilikan Terhadap Praktek Perataan Laba : Studi Empiris Perusahaan Manufaktur Yang Terdaftar di BEI", Simposium Nasional Akuntansi XIII. Purwokerto.

Anderson, Kirsten L., Daniel N Deli and Stuart L Gillan. 2003. "Boards Of Directors, Audit Committee, and The Information Content Of Earnings". WorkingPaper.September.

Anderson, R.C., S.A. Mansi, and D.M. Reeb. 2004. Founding Family Ownership and The Agency Cost of Debt. http:/www.ssrn.com.

Ball, R., A. Robin, and J. S. Wu. 2003. Incentives versus standards: properties of accounting income in four East Asian countries. Journal of Accounting and Economics 36 (1-3):235-270.

Beasley, Mark S., 1996. "An Empirical Analysis of he Relation Between the Board of Director Composition and Financial Statement Fraud". The AccountingReview, Vol.17. No.4, October, p.443-465.

Boediono, Gideon SB. 2005. "Kualitas Laba :Studi Pengaruh Mekanisme Corporate Governance dan Dampak Manajemen Laba Dengan Menggunakan Analisis Jalur", Simposium Nasional Akuntansi VIII. Solo.

Cespedes, J., et.al.2008. "The Separation of Ownership and Control in East Asian Corporations."Journal of Business Research, Vol 63, issue 3, pp.248-254

Chandrarin, G, 2003. "The Impact of Accounting Methods For Transaction Gains (Losses) on The Earnings Response Coefficient : The Indonesian Case", Jurnal Riset Akuntansi Indonesia. Vol. 6, No 3, September, hal.217-231.

Cheung, Y.L., Rau, P.R., Stouraitis, A., 2006. Tunneling, propping, and expropriation: Evidence from connected party transactions in Hong Kong. Journal of Financial Economics 82, 341-386.

Chtourou, SM., Jean Bedard, and Lucie Courteau, 2001, "Corporate Governance and Earnings Management".Working Paper.Universite Laval, Quebec City, Canada. April.

Claessens, S., Djankov, S., Lang, L., 2000. "The separation of ownership and control in East Asian Corporations".Journal of Financial Economics 58, 81-112. 
Claessens, S., Djankov, S., Fan, J., \& Lang, L. 2002. Disentangling the incentive and entrenchment effects of large shareholdings.Journal of Finance, 57, 2741-2771.

Dechow, P., Sloan, R., Sweeney, A., 1995. "Detecting earnings management".The Accounting Review 70 (April), 193-225.

Dechow P.M and Dichev I. D. 2002."The Quality of Accruals and Earnings: The Role of accrual Estimation Errors."http://papers.ssrn.com/sol3/papers. , diakses tanggal 11 Mei.

Demzets, Harold and Kenneth Lehn. 1983. The Structure of Corporate Ownership: Causes and Consequences. Journal of Political Economy,Vol.93. No.6. December, p.1155 - 1177

Dhaliwal, D. S., Salomon G. L., dan Smith, E. D. (1982). The Effect of Owner Versus Management Control on the Choice of Accounting Methods. Journal of Accounting and Economics, Vol.4.hal.41-53

Darmawati, D. et al., 2004, "Hubungan Corporate Governance dan Kinerja Perusahaan," Simposium Nasional Akuntansi VII, Denpasar

Egon Zehnder International. 2000. "Corporate and the role of the boards of directors".

Eisenhardt, Kathleem. M. 1989. "Agency Theory: An Assesment and Review". Academy of management Review, 14, hal 57-74

Fama E.F and Jensen M.C.,1983. "Separation Ownership And Control”. Journal of Law and Economics.Vol. 26, No 2 pp. 301-325.

Fan, J.P.H and Wong, T.J., 2002.“Corporate Ownership Structure and The Informativeness of accounting Earnings in East Asia".Journal of accounting and Economics.Vol. 33, pp. 401425.

Febrianto R dan Suwardjono. 2004. "The effect Of Ownership Concentration To Earning Quality", Sosiosains, 17 (4).

Febrianto R., Widiastuti E., 2006. "Tiga Angka Laba Akuntansi : Mana yang Lebih Bermakna bagi Investor?” Jurnal Riset Akuntansi Indonesia, Vol 9, Hal. 200-215

Financial Accounting Standards Boards. 1980. "Statement of Financial Accounting Concepts Nomor 2: Qualitative Characteristics of Accounting Information." Stanford, Connecticut. Mei.

Francis, J., LaFond, R., Olsson, P., Schipper, K., 2005. "The Market Pricing of Accruals Quality".Journal of Accounting and Economics 39, 295-327.

Gabrielsen, G., Gramlich J., and Plenborg, T. (2002)."Managerial ownership, information content of earnings, and discretionary accruals in a non-US setting", Journal of Business Finance and Accounting, 29(7\&8), 967-988.

Ghozali, Imam. 2005. Analisis Multivariate Lanjutan dengan Program SPSS. Semarang : BP Undip

Gujarati, Damodar. 2003. Basic Econometrics. Fourth Edition. New York: MC. Graw-Hill Inc. Jakarta: Erlangga.

Hendriksen, E.S. and Van Breda, M. 2001. Teori Akunting. Batam.Interaksara.

Ikatan Akuntan Indonesia. 2012. “Standar Akuntansi Keuangan." Jakarta: Salemba Empat. 
Indriantoro, N. dan Supomo, B. 1999." Metodologi Penelitian Akuntansi dan Manajemen”. BPFE, Yogyakarta.

Imaniar, Oktaviana. 2011. Pengaruh Komisaris Independen, Kepemilikan Institusional, Kepemilikan Manajerial, dan Kualitas Auditor terhadap Harga Saham (Studi pada Perushaan LQ-45 yang terdaftar di Bursa Efek Indonesia periode Agustus 2008 hingga Januari 2009). Skripsi, Jurusan Akuntansi FE Universitas Negeri Malang

Jaggi, B., S. Leung, dan F. Gul.2009. "Family Control, Board Independence ang Earning Management : Evidence based on Hong Kong Firms", J. Acccount. Public Policy, doi : 10.1016/j.jaccpubpol.06.002.

Jensen, M.C dan Meckling W.H. 1976."Theory of the Firm : Managerial Behavior, Agency Costs and Ownership Structure". Journal of Financial Economics, Vol 3, Issue.4, pp.305-360.

Jensen, M.C., 1993. "The Modern Industrial revolution, Exit, and the Failure of Internal Control System". Journal of Finance, Vol. 48. July, p.831-880.

Kieso D.E, Weygandt, J.J.,dan Warfield T.D. 2008. Intermediate Accounting.12 ed. Jakarta :Penerbit Erlangga.

Klein, April. 2002. "Audit Committee, Board Of Director Characteristics and Earnings Management". Journal of Accounting and Economics, Vol.33.No.3.August, p.375-400.

Komite Nasional Kebijakan Governance (KNKG).2006.Pedoman Umum Good Corporate Governance Indonesia. Jakarta.

Komite Nasional Kebijakan Governance (KNKG).2008.Pedoman Umum Good Corporate Governance Indonesia.Jakarta.

Kothari, S., Leone, A., Wasley, C., 2005.Performance Matched Discretionary Accrual Measures. Journal of Accounting and Economics 39.

La Porta, R., Lopez-de-Silanes, F., Schleifer, A., \& Vishny, R. 1999. Corporate ownership around the world.Journal offinance, 54, 471-517

La Porta, R., Lopez-de-Silanes, F.L., Shleifer, A., Vishny, R.W., 2002. Investor protection and corporate valuation. Journal of Finance 57 (3), 1147-1170.

Leuz, C., D. Nanda, and P. Wysocki. 2003. Earnings Management and Investor Protection: An International Comparison. Journal of Financial Economics 69 505-527.

Midiastuty, P.P dan Mahfoedz M. 2003.“Analisis Hubungan Mekanisme Corporate Governance dan Indikasi Manajemen Laba".Seminar NasionalAkuntansi VI.Hal.176-199. Surabaya.

Morck, R. A. Shleifer and R.W. Vishny. 1989. Alternative Mechanism for Corporate Control. American Economics Review. Vol.79. p.842-852

Pae, Jinhan. 1999. "Earnings Management and Its Impact on the Information Content of Earnings and the Properties of Analysts Forecasts." Thesis. Published. UMI.

Peasnell, K., Pope, P., Young, S., 2000.Accrual management to meet earnings targets: UK evidence pre- and post-Cadbury. The British Accounting Review 32 (4), 415-445. 
Peasnell, K.V, P.F. Pope., and S.Young. 2001. "Managerial Equity Ownership and The Demand for Outside Directors". Working Paper.October.

Scott, W.R. 2000. Financial Accounting Theory.2nd eition. Prentice Hall Canada Inc

Schipper, K., dan L. Vincent. 2003. Earnings quality. Accounting Horizons 17: 97-110

Sharma dan Durand. 1981.Identification and Analysis of Moderator Variabeles. Working Paper of University of Michigan

Shleifer, Andrei. dan Vishny, R.W., 1997. "A Survey of Corporate Governance".The Journal of Finance. June, Vol. 52 (2), 737-783.

Sloan, R. G. (1996). Do stock prices fully reflect information in accruals and cash flows about future earnings? AccountingReview, 71, 289-315.

Subramanyam, K. 1996. "The Pricing of Discretionary Accruals".Journal of Accounting and Economics, Vol.22.No.2.p.249-281.

Sutojo, S. dan Aldridge, E.J. 2005.Good Corporate Governance Tata Kelola Perusahaan yang Sehat.Damar Mulia Pustaka.

Teixeira, Alan M. 2002. "Assessing the Impact of a Change in the Level of ManagerDiscretion on the Informativeness of Earnings". Working Papers. Universityof Auckland. September.

Vafeas, Nikos. 2000. "Board Structure and Informativeness of Earnings" Journal of Accounting and Public Policy, Vol.19. p.139-160.

Veronica dan Bachtiar. 2004. “Good Corperate Governance, Information, Asymetry and Earning Management".SNA VII Denpasar. 